\title{
Biological Stabilisation of Tailing Pond Coasts with Use of Mineral and Organic Substances and Water-Absorbing Geocomposites
}

\author{
Leszek Kordas ${ }^{1}$, Piotr Kuc ${ }^{1 *}$, Krzysztof Lejcuś ${ }^{2}$ \\ 'Institute of Agroecology and Plant Production, Wrocław University of Environmental \\ and Life Sciences, Wrocław, Poland \\ ${ }^{2}$ Institute of Environmental Engineering, Wrocław University of Environmental and Life Sciences, Wrocław, Poland
}

Received: 23 June 2017

Accepted: 14 October 2017

\begin{abstract}
The aim of our study was to evaluate the influence of reclamation activities in a tailing pond, consisting in the application of mineral (rock aggregate) and organic substances (crop willow chips, swarf) and reclamation plants such as various species of grass and their mixtures with water-absorbing geocomposites, on the selected physical and biological parameters of the sediment. The experiment was started on Konrad tailing pond in Iwiny village in Poland. The pond had been filled with post-flotation sludge from copper ore mining until 1971. Since then, no activities have been conducted there. The mine tailings with absorbent (geocomposite) were characterised by higher moisture content. Intensified $\mathrm{CO}_{2}$ emissions were also noted, along with a noticeable reduction in the compactness of sediment in comparison to the values obtained for mine tailings without geocomposites. Various types of additives that were mixed with tailings in order to improve its disadvantageous physical and biological properties had a noticeable influence on mine tailings. The best results were obtained after using crop willow chips, which contributed to improved moisture conditions, reduced compactness, and increased amounts of emitted $\mathrm{CO}_{2}$. Individual species of reclamation plants or their mixtures had a relatively slight influence on the analysed properties of the post-flotation sediment. Significant differences were noted only for moisture content of the tails, which was highest after the introduction of switchgrass (Panicum virgatum L.).
\end{abstract}

Keywords: water-absorbing geocomposites, reclamation plants, tailings, reclamation

\section{Introduction}

Non-reclaimed flotation waste deposits created as a result of copper ore mining are harmful to the

*e-mail: piotr.kuc@upwr.edu.pl environment for many reasons. They contribute to water pollution and blowing out dust containing heavy metals, which may cause soil contamination and negatively affect the development of vegetation in their vicinity [1]. Due to the technology used in ore processing, flotation waste is characterised by a high share of very fine particles (usually around $85 \%$ ) and a very small share of skeletal parts, which has a negative influence 
on their physical properties [2-3]. Additionally, the disadvantageous growth conditions result from the alkaline $\mathrm{pH}$ and the presence of heavy metals - mainly copper and lead [4-5]. One of the ways to reclaim this type of tailing pond is to use various types of mineral materials, such as rock aggregate and organic material obtained from forestry waste. When mixed with soil, these materials are supposed to improve its physical and biological properties, which in turn enhances the conditions for growth and development of reclamation plants [6-9]. Plants used in the phytoremediation process should have the following properties: tolerance to high concentrations of heavy metals in tailings and the capacity to accumulate them, and resistance to stress factors such as salinization, acidification, or nutrient deficits [10]. Additional assets are a high growth rate and a large amount of produced biomass [11]. Grasses, especially those that use C4 photosynthesis path, are considered as useful species in the reclamation process - particularly in the initial phases. Their usability results from high tolerance to adverse conditions as well as the ability to quickly generate organic matter [12].

A disadvantageous parameter of flotation sediments that limits growth is high retention of water that remains inaccessible for plants. Water properties may be improved by modifying the granulometric composition and by applying various types of superabsorbents, also known as hydrogels or aerogels [13]. They have the form of loosely cross-linked ionic polymers (acrylic acid) or non-ionic polymers (polyacrylamide). What they all have in common is the ability to absorb significant amounts of water, even up to $1,000 \mathrm{~g}$ per $1 \mathrm{~g}$ of the absorbing substance. Apart from improving the water properties of soils [14-15], they also contribute to the improvement of structure and chemical properties of soil [16].

The experiment was conducted with the use of geocomposites developed at Wrocław University of Environmental and Life Sciences. They consist of a skeletal grid made from synthetic polymer, on which the superabsorbent (SAP) is placed. Such a structure enables free swelling of the gel and water retention and guarantees mechanical resistance to the pressure of soil from above. The external layer is made from nonwoven geotextile that enables free root growth and water infiltration [16-17].

The aim of the study was to evaluate the influence of modification of post-flotation sediment by the application of geocomposites, mineral and organic substances, and phytoremediation plants on the selected physical and biological parameters.

\section{Material and Methods}

The experiment was started in summer 2010 in the Konrad flotation waste deposit in Iwiny $\left(51^{\circ} 13^{\prime} 10.5^{\prime \prime} \mathrm{N}\right.$ $\left.15^{\circ} 39^{\prime} 45.2^{\prime \prime} \mathrm{E}\right)$. The main part of research was conducted in 2011-2013 based on a strict tri-factorial experiment set up with the use of the split-split-plot method, in 4 iterations.

The deposit in Iwiny, Poland, had been filled with mine tailings (post-flotation sediments) from the Ore Processing Department of the Konrad mining facility until 1971. Since then, no activities have been conducted there. It was only subject to natural plant succession. However, only birch, pine, and mosses appeared on the border areas, while reeds grew in the central part containing stagnated rainwater. In terms of granulometric composition, the sediment is a dustyclayey formation, with a marginal addition of sandy fraction and completely absent skeletal fractions [18-19].

The main plot of the experiment were the variants of mine tailing modification. Unmodified sediment was left in the control object. In the second variant, the sediment was mixed with crop willow chips (40 $\mathrm{mm}$ overburden), in the third one with rock aggregate ( $40 \mathrm{~mm}$ overburden), and in the fourth variant with $20 \mathrm{~mm}$ overburden of each rock aggregate and woodchips. All tailings additives were dug manually up to a depth of $20 \mathrm{~cm}$, and then mixed with use of a tiller.

The second experimental factor was the species or mixtures of reclamation plants. The plots were sown with reed canary grass (RCG) Phalaris arundicaea L. $\left(7 \mathrm{~g} \cdot \mathrm{m}^{-2}\right)+\mathrm{a}$ mixture of grasses ${ }^{1}(\mathrm{MM})\left(16 \mathrm{~g} \cdot \mathrm{m}^{-2}\right)$; switchgrass Panicum virgatum L. (S) $\left(9 \mathrm{~g} \cdot \mathrm{m}^{-2}\right)$; and reed canary grass (RCG) (Phalaris arundicaea L.) $\left(2.5 \mathrm{~g} \cdot \mathrm{m}^{-2}\right)+$ switchgrass Panicum virgatum L. (S) $\left(2.5 \mathrm{~g} \cdot \mathrm{m}^{-2}\right)+$ a mixture of grasses $(\mathrm{MM})\left(11 \mathrm{~g} \cdot \mathrm{m}^{-2}\right)$.

The third factor was the presence of water-absorbing geocomposites. Blocks of the dimensions $\mathrm{L}=74 \times \mathrm{xH}$ $=5.5 \times \mathrm{W}=9 \mathrm{~cm}$ were placed at a depth of $22 \mathrm{~cm}$ and covered with a layer of sediment.

Sediment respiration was measured with use of an EGM-4 infrared gas analyser with SRC-1 soil respiration chamber (PP systems, Hitchin, UK) in three repetitions on each experimental field. Volume moisture was determined with using an $\mathrm{HH} 2$ reader and an SM150 probe (Delta-T Devices Ltd., Cambridge, UK) set, also in 3 repetitions. Compactness up to a depth of $20 \mathrm{~cm}$ was determined with a tailings penetrometer with the function of electronic data recording in 8 repetitions per field.

The results were subjected to variance analysis. Border differences were determined with use of the Tukey test at confidence level $\alpha=0.05$.

\footnotetext{
Westerwold ryegrass Lolium multiflorum Lam. var. westerwoldicum 20\%, Common bentgrass Agrostis capillaris L. $20 \%$, Perennial ryegrass Lolium perenne L. 20\%, Red fescue Festuca rubra L. 20\%, Birdsfoot trefoil Lotus corniculatus L. $10 \%$, Crownvetch Coronilla varia L. 10\%
} 
Table 1. Activity of microorganism dehydrogenases in mine tailings $\left(\mu \mathrm{g} \mathrm{TF} \cdot \mathrm{g}^{-1} \cdot \mathrm{h}^{-1}\right)($ means for $2011-2013)$.

\begin{tabular}{|c|c|c|c|c|c|c|c|}
\hline \multirow{2}{*}{$\begin{array}{l}\text { Geo-compo- } \\
\text { sites }\end{array}$} & \multirow[b]{2}{*}{ Phytoremediation plants } & \multicolumn{5}{|c|}{ Additives for mine tailings } & \multirow[b]{2}{*}{ Mean } \\
\hline & & $\begin{array}{l}\text { Without } \\
\text { Additives }\end{array}$ & $\begin{array}{l}\text { Crop willow } \\
\text { chips }\end{array}$ & $\begin{array}{c}\text { Rock } \\
\text { aggregate }\end{array}$ & $\begin{array}{c}\text { Aggregate } \\
\text { +wood chips }\end{array}$ & Mean & \\
\hline \multirow{4}{*}{ Yes } & $\mathrm{RCG}+\mathrm{MM}$ & 0.30 & 0.50 & 0.30 & 0.38 & 0.37 & \multirow{4}{*}{0.44} \\
\hline & $\mathrm{S}$ & 0.55 & 0.64 & 0.45 & 0.43 & 0.52 & \\
\hline & $\mathrm{RCG}+\mathrm{S}+\mathrm{MM}$ & 0.32 & 0.50 & 0.30 & 0.55 & 0.42 & \\
\hline & Mean & 0.39 & 0.55 & 0.35 & 0.45 & - & \\
\hline \multirow{4}{*}{ No } & $\mathrm{RCG}+\mathrm{MM}$ & 0.22 & 0.50 & 0.39 & 0.51 & 0.41 & \multirow{4}{*}{0.40} \\
\hline & S & 0.32 & 0.49 & 0.25 & 0.36 & 0.36 & \\
\hline & $\mathrm{RCG}+\mathrm{S}+\mathrm{MM}$ & 0.40 & 0.48 & 0.29 & 0.60 & 0.44 & \\
\hline & Mean & 0.31 & 0.49 & 0.31 & 0.49 & - & \\
\hline \multirow{3}{*}{ Mean } & $\mathrm{RCG}+\mathrm{MM}$ & 0.26 & 0.50 & 0.35 & 0.45 & 0.39 & \multirow{4}{*}{-} \\
\hline & $\mathrm{S}$ & 0.44 & 0.57 & 0.35 & 0.40 & 0.44 & \\
\hline & $\mathrm{RCG}+\mathrm{S}+\mathrm{MM}$ & 0.36 & 0.49 & 0.30 & 0.58 & 0.43 & \\
\hline \multicolumn{2}{|r|}{ Mean } & 0.35 & 0.52 & 0.33 & 0.48 & - & \\
\hline
\end{tabular}

RCG - reed canary grass; $\mathrm{MM}$ - meadow mixture; $\mathrm{S}$ - switchgrass

Means followed by the same letters in the columns are significantly different at $\alpha \leq 0,05$; unmarked values do not differ significantly from each other at $\alpha \leq 0,05$; uppercase letters indicate differences among factors of experiment; lowercase letters indicate differences among interactions

\section{Results and Discussion}

The activity of microorganisms in tailings measured as the activity of dehydrogenase did not show significant correlation with any of the applied experimental factors or the interactions between them (Table 1). However, a relatively distinct effect of the additive into the tailings was noted. The application of wood material in the form of woodchips and woodchips mixed with rock aggregate led to a considerable increase in dehydrogenase activity, on average by $43 \%$, in comparison to sediment without additives. A similar trend after the application of organic matter was observed by Zornoza et al. [20] and Alvarenga et al. [21]. The addition of geocomposites to the sediment also led to increased enzyme activity by $10 \%$. Individual plants as well as their mixtures did not significantly affect the activity of microorganisms. Peng et al. [22] proved that enzyme activity depended more on the amount of biomass than on plant species.

The application of additives into the tails had a significant influence on water content (Table 2). The highest moisture content was noted after the application of crop willow chips, only $0.2 \%$ lower on fields with only flotation sediment. The addition of rock aggregate and rock aggregate mixed with woodchips resulted in a moisture content decrease by $7.7 \%$ and $6.9 \%$, respectively. The addition of mineral component to the mine tailings probably increased the rate of capillary infiltration and thus enhanced the dynamics of moisture changes [18-19].
The application of various species of grass and their mixtures led to slight yet statistically significant changes in water content in the tailings. The highest moisture content was measured on fields with switchgrass, where it was on average $1.3 \%$ higher than in other variants. The introduction of geocomposites to the sediment resulted in a statistically significant increase in moisture content by $1.2 \%$. The effectiveness of sorbents was also demonstrated by Lejcuś et al. [14], Zhong et al. [15], and Roshani et al. [23].

The water content in mine tailings depended also on the interaction between the sediment additive and on the presence of geocomposites. The highest increase in moisture content (by 3.1\%) after the application of geocomposites was noted in fields with sediment and without additives.

The biological activity of sediment measured by the intensity of $\mathrm{CO}_{2}$ emission showed a significant correlation with the tailings additives and the presence of geocomposites (Table 3). The highest amounts of carbon dioxide were emitted by sediment with the addition of crop willow chips, and the obtained values were $17 \%$ higher than those in unmodified sediment. On the other hand, rock aggregate mixed with woodchips had a negative influence on the biological activity of the sediment. After the application of such a mixture, tailings respiration fell by $6.4 \%$ in comparison to the activity noted in fields without sediment additives, but that difference is not statistically significant. The increase of respiration rates after the application 
Table 2. Mine tailings water content \% vol.; means for 2011-2013).

\begin{tabular}{|c|c|c|c|c|c|c|c|}
\hline \multirow{2}{*}{$\begin{array}{l}\text { Geo-com- } \\
\text { posites }\end{array}$} & \multirow{2}{*}{ Phytoremediation plants } & \multicolumn{5}{|c|}{ Additives for mine tailings } & \multirow{2}{*}{ Mean } \\
\hline & & $\begin{array}{l}\text { Without } \\
\text { Additives }\end{array}$ & $\begin{array}{l}\text { Crop willow } \\
\text { chips }\end{array}$ & $\begin{array}{c}\text { Rock } \\
\text { aggregate }\end{array}$ & $\begin{array}{c}\text { Aggregate } \\
+ \text { wood chips }\end{array}$ & Mean & \\
\hline \multirow{4}{*}{ Yes } & $\mathrm{RCG}+\mathrm{MM}$ & 29.8 & 30.3 & 23.7 & 20.6 & 26.1 & \multirow{4}{*}{$26.5 \mathrm{~A}$} \\
\hline & $\mathrm{S}$ & 33.9 & 30.3 & 21.5 & 24.0 & 27.4 & \\
\hline & $\mathrm{RCG}+\mathrm{S}+\mathrm{MM}$ & 29.4 & 29.8 & 21.8 & 23.3 & 26.1 & \\
\hline & Mean & $31.0 \mathrm{a}$ & $30.1 \mathrm{a}$ & $22.3 \mathrm{~b}$ & $22.6 \mathrm{~b}$ & - & \\
\hline \multirow{4}{*}{ No } & $\mathrm{RCG}+\mathrm{MM}$ & 27.2 & 29.3 & 22.0 & 22.0 & 25.1 & \multirow{4}{*}{$25.3 \mathrm{~B}$} \\
\hline & S & 29.3 & 30.3 & 20.9 & 23.9 & 26.1 & \\
\hline & $\mathrm{RCG}+\mathrm{S}+\mathrm{MM}$ & 27.3 & 28.4 & 21.0 & 21.6 & 24.6 & \\
\hline & Mean & $27.9 \mathrm{c}$ & $29.3 \mathrm{a}$ & $21.3 \mathrm{~b}$ & $22.5 \mathrm{~b}$ & - & \\
\hline \multirow{3}{*}{ Mean } & $\mathrm{RCG}+\mathrm{MM}$ & 28.5 & 29.8 & 22.9 & 21.3 & $25.6 \mathrm{~A}$ & \multirow{4}{*}{-} \\
\hline & $\mathrm{S}$ & 31.6 & 30.3 & 21.2 & 24.0 & $26.8 \mathrm{~B}$ & \\
\hline & $\mathrm{RCG}+\mathrm{S}+\mathrm{MM}$ & 28.4 & 29.1 & 21.4 & 22.5 & $25.4 \mathrm{~A}$ & \\
\hline & Mean & $29.5 \mathrm{~A}$ & $29.7 \mathrm{~A}$ & $21.8 \mathrm{~B}$ & $26.6 \mathrm{C}$ & - & \\
\hline
\end{tabular}

Means followed by the same letters in the columns are significantly different at $\alpha \leq 0,05$; unmarked values do not differ significantly from each other at $\alpha \leq 0,05$; uppercase letters indicate differences among factors of experiment; lowercase letters indicate differences among interactions

For abbreviation explanations see Table 1.

of organic residues as well as including both mineral and organic ones was observed by Zornoza et al. [24]. Moreno-Barriga et al. [3] observed that $\mathrm{CO}_{2}$ emissions were not significantly affected by any of the used amendment. The presence of geocomposites led to an increase in respiration by $18.5 \%$ in comparison to tails

Table 3. Sediment respiration $\left(\mathrm{g} \mathrm{CO}_{2} \cdot \mathrm{m}^{-2} \cdot \mathrm{h}^{-1}\right.$; means for $\left.2011-2013\right)$.

\begin{tabular}{|c|c|c|c|c|c|c|c|}
\hline \multirow{2}{*}{$\begin{array}{l}\text { Geo-compo- } \\
\text { sites }\end{array}$} & \multirow{2}{*}{ Phytoremediation plants } & \multicolumn{5}{|c|}{ Additives for mine tailings } & \multirow{2}{*}{ Mean } \\
\hline & & $\begin{array}{l}\text { Without } \\
\text { Additives }\end{array}$ & $\begin{array}{l}\text { Crop willow } \\
\text { chips }\end{array}$ & $\begin{array}{c}\text { Rock } \\
\text { aggregate }\end{array}$ & $\begin{array}{c}\text { Aggregate } \\
\text { +wood chips }\end{array}$ & Mean & \\
\hline \multirow{4}{*}{ Yes } & $\mathrm{RCG}+\mathrm{MM}$ & 0.54 & 0.57 & 0.47 & 0.56 & 0.54 & \multirow{4}{*}{$0.50 \mathrm{~A}$} \\
\hline & S & 0.46 & 0.55 & 0.47 & 0.45 & 0.48 & \\
\hline & $\mathrm{RCG}+\mathrm{S}+\mathrm{MM}$ & 0.42 & 0.52 & 0.55 & 0.46 & 0.49 & \\
\hline & Mean & $0.47 \mathrm{ac}$ & $0.55 \mathrm{~b}$ & $0.50 \mathrm{a}$ & $0.49 \mathrm{ac}$ & - & \\
\hline \multirow{4}{*}{ No } & $\mathrm{RCG}+\mathrm{MM}$ & 0.47 & 0.56 & 0.43 & 0.41 & 0.47 & \multirow{4}{*}{$0.46 \mathrm{~B}$} \\
\hline & $\mathrm{S}$ & 0.48 & 0.57 & 0.44 & 0.32 & 0.45 & \\
\hline & $\mathrm{RCG}+\mathrm{S}+\mathrm{MM}$ & 0.45 & 0.49 & 0.42 & 0.43 & 0.45 & \\
\hline & Mean & $0.47 \mathrm{ac}$ & $0.54 \mathrm{~b}$ & $0.43 \mathrm{~cd}$ & $0.39 \mathrm{~d}$ & - & \\
\hline \multirow{3}{*}{ Mean } & $\mathrm{RCG}+\mathrm{MM}$ & 0.51 & 0.57 & 0.45 & 0.49 & 0.51 & \multirow{4}{*}{-} \\
\hline & $\mathrm{S}$ & 0.47 & 0.56 & 0.46 & 0.39 & 0.47 & \\
\hline & $\mathrm{RCG}+\mathrm{S}+\mathrm{MM}$ & 0.44 & 0.51 & 0.49 & 0.45 & 0.47 & \\
\hline & Mean & $0.47 \mathrm{~A}$ & $0.55 \mathrm{~B}$ & $0.47 \mathrm{~A}$ & $0.44 \mathrm{~A}$ & - & \\
\hline
\end{tabular}

Means followed by the same letters in the columns are significantly different at $\alpha \leq 0,05$; unmarked values do not differ significantly from each other at $\alpha \leq 0,05$; uppercase letters indicate differences among factors of experiment; lowercase letters indicate differences among interactions

For abbreviation explanations see Table 1 . 
Table 4. Sediment compaction in layer 0-10 cm (MPa; means for 2011-2013).

\begin{tabular}{|c|c|c|c|c|c|c|c|}
\hline \multirow{2}{*}{$\begin{array}{l}\text { Geo-compo- } \\
\text { sites }\end{array}$} & \multirow[b]{2}{*}{ Phytoremediation plants } & \multicolumn{5}{|c|}{ Additives for mine tailings } & \multirow[b]{2}{*}{ Mean } \\
\hline & & $\begin{array}{l}\text { Without } \\
\text { Additives }\end{array}$ & $\begin{array}{c}\text { Crop willow } \\
\text { chips }\end{array}$ & $\begin{array}{c}\text { Rock } \\
\text { aggregate }\end{array}$ & $\begin{array}{c}\text { Aggregate } \\
\text { +wood chips }\end{array}$ & Mean & \\
\hline \multirow{4}{*}{ Yes } & $\mathrm{RCG}+\mathrm{MM}$ & 1.47 & 1.52 & 1.63 & 1.58 & $1.55 \mathrm{a}$ & \multirow{4}{*}{$1.49 \mathrm{~A}$} \\
\hline & $\mathrm{S}$ & 1.43 & 1.15 & 1.49 & 1.43 & $1.38 \mathrm{~b}$ & \\
\hline & $\mathrm{RCG}+\mathrm{S}+\mathrm{MM}$ & 1.43 & 1.39 & 1.72 & 1.59 & $1.53 \mathrm{a}$ & \\
\hline & Mean & 1.44 & 1.35 & 1.61 & 1.53 & - & \\
\hline \multirow{4}{*}{ No } & $\mathrm{RCG}+\mathrm{MM}$ & 1.71 & 1.51 & 1.56 & 1.50 & $1.57 \mathrm{a}$ & \multirow{4}{*}{$1.58 \mathrm{~B}$} \\
\hline & $\mathrm{S}$ & 1.69 & 1.32 & 1.73 & 1.75 & $1.62 \mathrm{a}$ & \\
\hline & $\mathrm{RCG}+\mathrm{S}+\mathrm{MM}$ & 1.61 & 1.21 & 1.74 & 1.58 & $1.54 \mathrm{a}$ & \\
\hline & Mean & 1.67 & 1.35 & 1.68 & 1.61 & - & \\
\hline \multirow{3}{*}{ Mean } & $\mathrm{RCG}+\mathrm{MM}$ & 1.59 & 1.52 & 1.60 & 1.54 & 1.56 & \multirow{4}{*}{-} \\
\hline & $\mathrm{S}$ & 1.56 & 1.24 & 1.61 & 1.59 & 1.50 & \\
\hline & $\mathrm{RCG}+\mathrm{S}+\mathrm{MM}$ & 1.52 & 1.30 & 1.73 & 1.59 & 1.53 & \\
\hline & Mean & $1.56 \mathrm{~A}$ & $1.35 \mathrm{~B}$ & $1.65 \mathrm{C}$ & $1.57 \mathrm{~A}$ & - & \\
\hline
\end{tabular}

Means followed by the same letters in the columns are significantly different at $\alpha \leq 0,05$; unmarked values do not differ significantly from each other at $\alpha \leq 0,05$; uppercase letters indicate differences among factors of experiment; lowercase letters indicate differences among interactions

For abbreviation explanations see Table 1.

without absorbent. In spite of their high molecular mass, geocomposites decompose slowly [25], which results in the increased $\mathrm{CO}_{2}$ emissions from tailings [26].
The amount of emitted $\mathrm{CO}_{2}$ depended on the interaction between sediment additives and the presence of geocomposites. After their application into the mine

Table 5. Sediment compaction in layer 10-20 cm (MPa; means for 2011-2013).

\begin{tabular}{|c|c|c|c|c|c|c|c|}
\hline \multirow{2}{*}{$\begin{array}{l}\text { Geo-compo- } \\
\text { sites }\end{array}$} & \multirow[b]{2}{*}{ Phytoremediation plants } & \multicolumn{5}{|c|}{ Additives for mine tailings } & \multirow{2}{*}{ Mean } \\
\hline & & $\begin{array}{l}\text { Without } \\
\text { Additives }\end{array}$ & $\begin{array}{l}\text { Crop willow } \\
\text { chips }\end{array}$ & $\begin{array}{c}\text { Rock } \\
\text { aggregate }\end{array}$ & $\begin{array}{c}\text { Aggregate } \\
\text { +wood chips }\end{array}$ & Mean & \\
\hline \multirow{4}{*}{ Yes } & $\mathrm{RCG}+\mathrm{MM}$ & 1.55 & 1.48 & 1.56 & 1.60 & 1.55 & \multirow{4}{*}{$1.58 \mathrm{~A}$} \\
\hline & $\mathrm{S}$ & 1.54 & 1.55 & 1.70 & 1.56 & 1.59 & \\
\hline & $\mathrm{RCG}+\mathrm{S}+\mathrm{MM}$ & 1.61 & 1.57 & 1.74 & 1.53 & 1.61 & \\
\hline & Mean & $1.57 \mathrm{a}$ & $1.53 \mathrm{a}$ & $1.67 \mathrm{a}$ & $1.56 \mathrm{a}$ & - & \\
\hline \multirow{4}{*}{ No } & $\mathrm{RCG}+\mathrm{MM}$ & 2.17 & 1.91 & 1.91 & 1.85 & 1.96 & \multirow{4}{*}{$2.02 \mathrm{~B}$} \\
\hline & $\mathrm{S}$ & 2.20 & 1.94 & 2.14 & 2.03 & 2.08 & \\
\hline & $\mathrm{RCG}+\mathrm{S}+\mathrm{MM}$ & 2.24 & 1.83 & 2.01 & 1.98 & 2.02 & \\
\hline & Mean & $2.20 \mathrm{~b}$ & $1.89 \mathrm{c}$ & $2.02 \mathrm{c}$ & $1.95 \mathrm{c}$ & - & \\
\hline \multirow{3}{*}{ Mean } & $\mathrm{RCG}+\mathrm{MM}$ & 1.86 & 1.70 & 1.74 & 1.73 & 1.76 & \multirow{4}{*}{-} \\
\hline & $\mathrm{S}$ & 1.87 & 1.75 & 1.92 & 1.80 & 1.84 & \\
\hline & $\mathrm{RCG}+\mathrm{S}+\mathrm{MM}$ & 1.93 & 1.70 & 1.88 & 1.76 & 1.82 & \\
\hline & Mean & 1.89 & 1.72 & 1.85 & 1.76 & - & \\
\hline
\end{tabular}

Means followed by the same letters in the columns are significantly different at $\alpha \leq 0,05$; unmarked values do not differ significantly from each other at $\alpha \leq 0,05$; uppercase letters indicate differences among factors of experiment; lowercase letters indicate differences among interactions

For abbreviation explanations see Table 1. 
Table. 6. Linear correlation coefficients (r) between tailings compaction and selected parameters.

\begin{tabular}{|c|c|c|c|}
\hline Mine tailings parameters & Tailings respiration & Water content & $\begin{array}{c}\text { Activity of dehydroge- } \\
\text { nases }\end{array}$ \\
\hline Compaction in layer $0-10 \mathrm{~cm}$ & -0.400 & $-0.546^{*}$ & $-0.486^{*}$ \\
\hline Compaction in layer $10-20 \mathrm{~cm}$ & -0.377 & -0.209 & $-0.503^{*}$ \\
\hline
\end{tabular}

*Significant correlation $(\alpha=0.05)$

tailings, the highest increase in activity, by $20.4 \%$, was noted in the sediment with the addition of rock aggregate mixed with woodchips. However, their presence in unmodified sediment did not affect the intensity of gas exchange.

Although plant species and their mixes did not significantly affect the amount of $\mathrm{CO}_{2}$, the highest respiration rate was observed on plots with RCG+MM. Plant growth may improve microbiological function of tailings [27], but this is correlated with vegetation cover and amount of biomass [28].

The introduction of additives to the sediments and the presence of geocomposites led to considerable changes in tail compactness in the $0-10 \mathrm{~cm}$ layer (Table 4). The highest compactness was noted in tailings containing rock aggregate, which was $5.8 \%$ higher than the values obtained for sediment without additives. On the other hand, the application of crop willow chips had the most beneficial influence on the compactness as it was reduced by $13.5 \%$ in comparison with the object without additives. Improvement of physical quality on mine tailings after the addition of organic amendments was observed by Muñoz et al. [29]. The application of geocomposites allowed us to reduce sediment compactness by $5.7 \%$. Phytoremediation plants, in spite of species diversity, did not significantly affect soil compaction. This was probably caused by slight differences in their biomass gain during vegetation.

Interaction analysis enabled us to demonstrate that mine tailings compactness changed considerably depending on the interaction between the presence of geocomposites and the species of grass or their mixtures. After the introduction of absorbent, the lowest compactness was noted in fields sown with switchgrass. It was, on average, $10.4 \%$ lower than in the other variants. A reverse correlation, but not statistically proven, was manifested in fields without geocomposites, where sowing switchgrass resulted in increased compactness in comparison to the remaining objects. In the deeper sediment layer $(10-20 \mathrm{~cm}$, Table $5)$, the differences were smaller and significantly dependent only on the presence of geocomposites and the interaction between this factor and the type of reclamation plants. Similarly to the $0-10 \mathrm{~cm}$ layer, the application of geocomposites resulted in a significant reduction in tails compactness by as much as $22.7 \%$. The interaction analysis demonstrated that the application of absorbent allowed for the highest compactness reduction in fields sown with switchgrass.
The conducted analysis of linear correlation demonstrated that only compactness was significantly, though slightly, correlated with certain parameters of the mine tailings (Table 6). The activity of dehydrogenases showed a significant negative correlation with sediment compactness, both in the $0-10 \mathrm{~cm}$ layer and in the deeper 10-20 cm layer. A negative correlation between moisture content and tails compactness in the $0-10 \mathrm{~cm}$ layer was also confirmed.

\section{Conclusions}

1. The application of water-absorbing geocomposites contributed to the improvement of the physical and biological properties of the tailings pond. The mine tailings with superabsorbent was characterised by higher moisture content. Intensified gas exchange was also noted, along with a noticeable reduction in the compactness of sediment in comparison to the values obtained for tails without geocomposites.

2. Various types of additives that were mixed with mine tailings in order to improve the disadvantageous properties had a noticeable influence on selected tailings parameters. The best results were obtained after the application of crop willow chips, which led to improved moisture conditions, reduced compactness, and intensified $\mathrm{CO}_{2}$ emissions.

3. Individual species of reclamation plants or their mixtures had a relatively slight influence on the analysed properties of flotation sediment. Significant differences were noted only for moisture content of the mine tailings, which was the highest after the introduction of switchgrass (Panicum virgatum L.).

\section{Acknowledgements}

Research was conducted as part of the interdisciplinary project 'Water-absorbing geocomposites: innovative technologies supporting plant growth' (No. UDAPOIG. 01.03.01-00-181/09-00 carried out under the Operational Programme Innovative Economy cofinanced by the European Union from the European Regional Development Fund).

\section{References}

1. ZANUZZI A., AROCENA J.M., VAN MOURIK J.M., CANO A.F. Amendments with organic and industrial 
wastes stimulate soil formation in mine tailings as revealed by micromorphology. Geoderma. 154, 69, 2009.

2. MARTÍNEZ-PAGÁN P., FAZ A., ACOSTA J.A., CARMONA D.M., MARTÍNEZ-MARTÍNEZ S. A multidisciplinary study for mining landscape reclamation: a study case on two tailing ponds in the Region of Murcia (SE Spain) Phys. Chem. Earth. 36, 1331, 2011.

3. MORENO-BARRIGA F., DÍAZ V., ACOSTA J.A., MUÑOZ M.Á., FAZ Á., ZORNOZA R. Organic matter dynamics, soil aggregation and microbial biomass and activity in Technosols created with metalliferous mine residues, biochar and marble waste. Geoderma. 301, 19, 2017.

4. RYBAK J., KRAWCZYŃSKA M., BIAZIK J., KOŁCZAN B., GRABAS K. Phytotoxicity of flotation tailings in area of Iwiny (Flotation tank Konrad, Warta Bolesławiecka). Materiały z II konferencji naukowej „Ekotoksykologia w ochronie środowiska“, Szklarska Poręba. 343, 2008 [In Polish].

5. PATRZAŁEK A., POZZI M. Physical and Chemical Properties of Topsoil Used for Biological Restoration of Coal Mine Waste - Based Structures in Upper Silesian Coal Basin $24^{\text {th }}$ Meeting American Society of Mining and Reclamation, Gillette, Wyoming. 618, 2007.

6. CABAŁA A., WRÓBLEWSKA K., CHOHURA P., DĘBICZ R. Effect of fertilization through geocomposite on nutritional status of Hosta 'halcyon' plants grown in containers. Acta Sci. Pol. Hortorum Cultus. 15 (3), 83, 2016.

7. KRAWCZYŃSKA M., KOŁWZAN B., GEDIGA K., DZIUBEK A., GRABAS K., KARPENKO E. Evaluation of the possibility of phytostabilization of post-flotation tailing ponds. Environment Protection Engineering. 41, 157, 2015.

8. SHEORAN V., SHEORAN A.S., POONIA P. Soil reclamation of abandoned mine land by revegetation: a review. Int. J. Soil Sediment Water. 3 (2), Article 13, 2010.

9. SPIAK Z., GEDIGA K. Usefulness of selected mineral wastes for reclamation of copper industry dumping site. Environ. Prot. Eng. 35 (1), 79, 2009.

10. WU Y., LI Y., ZHENG C., ZHANG Y., SUN Z. Organic amendment application influence soil organism abundance in saline alkali soil. Eur. J. Soil Biol. 54, 32, 2013.

11. MARQUES A.P., RANGEL A.O., CASTRO P.M. Remediation of heavy metal contaminated soils: phytoremediation as a potentially promising clean-up technology. Crit. Rev. Environ. Sci. Technol. 39 (8), 622, 2009.

12. SHEORAN V., SHEORAN A.S., POONIA P. Soil reclamation of abandoned mine land by revegetation: a review. Int J Soil Sediment Water. 3 (2), 13, 2010.

13. AGABA H., BAGUMA ORIKIRIZA L.J., ESEGU O., FRANCIS J., OBUA J., KABASA J.D., HÜTTERMANN A. Effects of hydrogel amendment to different soils on plant available water and survival of trees under drought conditions. Clean-Soil, Air, Water. 38 (4), 328, 2010.

14. LEJCUŚ K., DĄBROWSKA J., GARLIKOWSKI D., KORDAS L. Water loss from soil and water absorbing geocomposite. International Proceedings of Chemical Biological \& Environmental Engineering, Environmental Science and Technology VI. 84, 123, 2015.

15. ZHONG K., LIN Z.T., ZHENG X.L., JIANG G.B., FANG Y.S., MAO X.Y., LIAO Z.W. Starch derivative-based superabsorbent with integration of water-retaining and controlled-release fertilizers. Carbohydrate polymers. 92 (2), 1367, 2013.

16. LEJCUŚ K., DĄBROWSKA J. Characteristics of selected properties of superabsorbents. Infrastructure and ecology of rural areas. 3 (4), 59, 2012.

17. LEJCUŚ K., DĄBROWSKA J., GARLIKOWSKI D., ŚPITALNIAK M. The application of water-absorbing geocomposites to support plant growth on slopes. Geosynth. Int. 22 (6), 452, 2015.

18. CHODAK T., KASZUBKIEWICZ J., MIZERA A. Researches of soil-forming value of flotation tailings and waste rock disposal site K-I in the Iwiny region in the aspect of their susceptibility to reclamation works. Cuprum Ore Mining Scientific and Technical Magazine. 34 (1), 57, 2005 [In Polish].

19. KASZUBKIEWICZ J., MARCZYK M., MIZERA A. Analysis of properties the copper slag for its use to reclamation the old tailing pond of copper mining. Scientific Journal of Wrocław University of Environmental and Life Sciences - Agronomy. 91 (560), 13, 2007 [In Polish].

20. ZORNOZA R., FAZ Á., CARMONA D.M., ACOSTA J.A., MARTÍNEZ-MARTÍNEZ S., DE VRENG A. Carbon mineralization, microbial activity and metal dynamics in tailing ponds amended with pig slurry and marble waste. Chemosphere. 90, 2606, 2013.

21. ALVARENGA P., GONÇALVES A.P., FERNANDES R.M., DE VARENNES A., VALLINI G., DUARTE E., CUNHA-QUEDA A.C. Evaluation of composts and liming materials in the phytostabilization of a mine soil using perennial ryegrass. Science of the Total Environment. 406 (1), 43, 2008.

22. PENG X.Z., YANG S.X., LI F.M., CAO J.B., PENG Q.J. Effects of Three Industrial Organic Wastes as Amendments on Plant Growth and the Biochemical Properties of a $\mathrm{Pb} / \mathrm{Zn}$ Mine Tailings. J Environ Sci (China). 37 (1), 301, 2016.

23. ROSHANI A., FALL M., KENNEDY K. Impact of drying on geo-environmental properties of mature fine tailings pre-dewatered with super absorbent polymer. Int. J. Environ. Sci. Technol. 14 (3), 453, 2017.

24. ZORNOZA R., CANO A.F., CARMONA D.M., ACOSTA J.A., MARTÍNEZ-MARTÍNEZ S., KABAS S. Carbon mineralization in mine tailing ponds amended with pig slurries and marble wastes. Eurasian J.Soil Sci. 1 (2), 104, 2012.

25. OKSIŃSKA M., MAGNUCKA E., LEJCUŚ K., PIETR S. Biodegradation of the cross-linked copolymer of acrylamide and potassium acrylate by soil bacteria. Environ. Sci. Pollut. R. 23 (6), 5969, 2016.

26. HOLLIMAN P.J., CLARK J.A., WILLIAMSON J.C., JONES D.L. Model and field studies of the degradation of cross-linked polyacrylamide gels used during the revegetation of slate waste. Sci. Total Environ. 336 (1), 13, 2005.

27. KUMPIENE J., GUERRI G., LANDI L., PIETRAMELLARA G., NANNIPIERI P., RENELLA G. Microbial biomass, respiration and enzyme activities after in situ aided phytostabilization of a $\mathrm{Pb}$-and $\mathrm{Cu}$ contaminated soil. Ecotoxicol. Environ. Saf. 72 (1), 115, 2009.

28. YANG S., CAO J., LI F., PENG X., PENG Q., YANG Z., CHAI L. Field evaluation of the effectiveness of three industrial by-products as organic amendments for phytostabilization of a $\mathrm{Pb} / \mathrm{Zn}$ mine tailings. Environ. Sci. Process. Impact. 18 (1), 95, 2016.

29. MUÑOZ M.A., GUZMAN J.G., ZORNOZA R., MORENO F., FAZ A., LAL R. Effects of biochar and marble mud on mine waste properties to reclaim tailing ponds. Land Degrad. Dev. 27 (4), 1227, 2016. 